\title{
Beskrivende radiografer er ikke løsningen
}

\author{
A la radiografer beskrive røntgenbilder er foreslått som løsning på et ikke definert kapasitetsproblem. Dette \\ har ført til en debatt i det radiologiske miljøet, og flere viktige spørsmål stilles: Tas det for mange røntgen- \\ bilder? Hvordan organiseres det bildediagnostiske arbeidet best? Hvilken retning ønsker vi for faget vårt?
}

Styret i Norsk radiologisk forening er takknemlig for debatten om å la radiografer beskrive røntgenbilder (1-3). Men å utdanne beskrivende radiografer er en «løsning» på et problem som etter styrets syn ikke er godt definert. Det hevdes at det er radiologmangel. Det er et vidt begrep som er avhengig av mange forhold: Antall henvisninger, hvorvidt undersøkelsen er berettiget - og hvor god service samfunnet er villig til å betale for. Dette er således vel så mye et politisk som et medisinsk spørsmål. Antall radiologer per innbygger i Norge er etter Sverige det høyeste i Europa, men med dagens etterspørsel etter undersøkelser og organisering av det bildediagnostiske arbeidet, er vi øyensynlig likevel underbemannet.

For flere radiologiske avdelinger er det tolkningskapasiteten som er mest begrenset, ikke selve bildetakingen. Når det ligger flere undersøkelser til beskrivelse enn det radiologene klarer å håndtere, er trolig kapasiteten til å gjøre undersøkelsen for høy. Ønskes økt kapasitet til å beskrive undersøkelser, bør arbeidsflyten for radiologen optimaliseres og/eller utdanningskapasiteten for radiologer økes. Det er god søknad til utlyste utdanningsstillinger i radiologi.

Mulighetene og behovet for etterbehandling av bildeundersøkelser er stadig økende, og vårt teknologitunge fag har langt fra optimale IKT-løsninger. Radiografer har her store utviklingsmuligheter. Likevel er det påfallende lite diskusjon om hvordan man kan legge forholdene til rette for effektivisering av drift, bedre rutiner bl.a. på henvisninger, utføring av merkantile oppgaver, etterbehandling og presentasjon av bilder slik at kapasiteten utnyttes best mulig.

\section{Medisinsk bakgrunn}

Den planlagte etterutdanningen for å bli beskrivende radiograf består av 1,5 års deltidsstudium (4). Selv om man i hverdagen som radiolog ikke jobber direkte med alt man har lært gjennom seks års grunnutdanning i medisin, er all kunnskapen man har tilegnet seg direkte eller indirekte med på å forme hvordan vi jobber og hvilke avgjørelser vi tar. Etter om lag tre måneders spesialisering i radiologi regnes leger i spesialisering som vaktkompetente med grunnleggende kunnskap innen de vanligste modaliteter og er dermed langt mer fleksibel enn en beskrivende radiograf.

Norsk radiologisk forening anser beskrivende radiografer som en kortsiktig og lite fleksibel løsning. Leger i spesialisering i radiologi som får tilstrekkelig volum av undersøkelser og ditto veiledning vil etter relativt sett kort tid være i stand til å diagnostisere de vanligste tilstandene man kan se ved hjelp av radiologi, ultralyd og CT, ikke kun konvensjonell røntgen av skjelett.

\section{Spesialisering i radiologi}

Leger i spesialisering i radiologi har i lengre tid rapportert at det kan være vanskelig å få tilstrekkelig veiledning og oppfølging fra overleger. Det berettes om høy forvent-

\section{«Radiologien ivaretas best ved at radiologer står for bildediagnos- tiseringen av pasien-} tene»

ning til produksjon og flere leger i spesialisering føler de ikke kan riktig fordype seg i undersøkelser i læringsøyemed. Dersom radiografer må læres opp av overleger ved radiologisk avdeling, vil dette både gå på bekostning av veiledningen og overlegenes generelle granskningstid.

\section{Spesielle behov}

Det finnes store regionale forskjeller, og enkelte steder kan det være en god løsning å la radiografer overta noe av det diagnostiske arbeidet. Norsk radiologisk forening mener like fullt at disse lokale tilpasningene ikke forsvarer oppstart av egne utdanningsløp ved norske høyskoler så lenge det finnes etablerte utdanningsinstitusjoner i utlandet.

\section{Radiologer bør fortsatt gjøre jobben} Økt forventning til kvalitet, kvantitet og effektivitet vil være en utfordring også i fremtiden, men det bør ikke være et argument for å senke kompetansekravene til utøvere i helsevesenet. Norsk radiologisk forening mener at radiologien ivaretas best ved at radiologer, som fagpersoner med bred medisinskfaglig bakgrunn, står for bildediagnostiseringen av pasientene. Det er ikke behov for eget utdanningsopplegg for beskrivende radiografer ved norske høyskoler.

\author{
Gaute Hagen \\ gaute.hagen@rikshospitalet.no \\ Raymond Brønn \\ Per Kristian Hol \\ Bente Lund Neple \\ Peter Mæhre Lauritzen \\ Helga M. Brøgger \\ Billy Roger Parimalasingham \\ Lars Hagen Henriksen \\ Tanja Rønsen
}

Gaute Hagen (f. 1958) er overlege ved Enhet for abdominal radiologi, Oslo universitetssykehus, Rikshospitalet, og er leder for Norsk radiologisk forening

Forfatter har fylt ut ICMJE-skjemaet og oppgir ingen interessekonflikter.

Raymond Brønn (f. 1977) er overlege ved Curato Røntgen Trondheim og nestleder i Norsk radiologisk forening

Forfatter har fylt ut ICMJE-skjemaet og oppgir ingen interessekonflikter.

Per Kristian Hol (f. 1952) er radiolog ved Intervensjonssenteret, Oslo universitetssykehus, professor ved Universitetet i Oslo og vitenskapelig sekretær i Norsk radiologisk forening. Forfatter har fylt ut ICMJE-skjemaet og oppgir ingen interessekonflikter.

Bente Lund Neple (f. 1982) er lege i spesialisering i radiologi ved Diakonhjemmet sykehus og styremedlem i Norsk radiologisk forening.

Forfatter har fylt ut ICMJE-skjemaet og oppgir ingen interessekonflikter.

Peter Mæhre Lauritzen (f. 1978) er forsker ved Akershus universitetssykehus og styremedlem i Norsk radiologisk forening.

Forfatter har fylt ut ICMJE-skjemaet og oppgir følgende interessekonflikter: Han har mottatt støtte fra Den norske legeforening.

Helga M. Brøgger (f. 1974) er overlege ved Enhet for MSK-radiologi, Oslo universitetssykehus, Ullevål, og styremedlem i Norsk radiologisk forening

Forfatter har fylt ut ICMJE-skjemaet og oppgir ingen interessekonflikter.

Billy Roger Parimalasingham (f. 1982) er lege i spesialisering i radiologi ved St. Olavs hospital og styremedlem i Norsk radiologisk forening. Forfatter har fylt ut ICMJE-skjemaet og oppgir ingen interessekonflikter.

Lars Hagen Henriksen (f. 1952) er overlege i radiologi ved Sykehuset Innlandet Lillehammer og varamedlem i styret for Norsk radiologisk forening.

Forfatter har fylt ut ICMJE-skjemaet og oppgir ingen interessekonflikter. 
Tanja Rønsen (f. 1973) er overlege i radiologi ved Stavanger universitetssjukehus og varamedlem i styret i Norsk radiologisk forening. Forfatter har fylt ut ICMJE-skjemaet og oppgir ingen interessekonflikter.

\section{Litteratur}

1. Norsk radiologisk forening. Beskrivende radiografer. http://legeforeningen.no/Fagmed/Norskradiologisk-forening/Nyheter/Foreningsstoff/ Beskrivende-radiografer (1.6.2016)

2. Vigeland E, Hager AM. La radiografer beskrive røntgenbilder! Tidsskr Nor Legeforen 2016; 136 600

3. Norsk radiologisk forening. Om beskrivende radiograf. http://legeforeningen.no/Fagmed/Norskradiologisk-forening/Nyheter/Foreningsstoff/ Om-beskrivende-radiograf/ (1.6.2016).

4. Høgskolen i Oslo og Akershus. Programplan for videreutdanning av radiografer - tolkning og beskrivelse av skjelettrøntgenbilder. www.hioa.no/ Studies/HF/Evu/Tolking-og-beskrivelse-avskjelettroentgenbilder/Programplan-for-

Videreutdanning-for-radiografer-tolking-ogbeskrivelse-av-skjelettroentgenbilder-kull-2016 (1.6.2016)

Mottatt 18.5. 2016, første revisjon innsendt 2.6.

2016, godkjent 9.6. 2016. Redaktør: Ketil Slagstad.

Publisert først på nett. 